\title{
СПРАВЕДЛИВОЕ ОБЩЕСТВО КАК ПРОЕКТ БУДУЩЕГО В ФИЛОСОФИИ А. М. КОВАЛЁВА
}

\begin{abstract}
Аннотация: В статье исследуются основные идеи проекта справедливого общества в философии современного российского философа А. М. Ковалёва. Социально-справедливое общество рассматривается как проект возможного общества будущего. Конщепџия справедливости А. М. Ковалёва исследуется как оригинальное учение в свете обогащения данной проблематики. Автор рассматривает данный проект как отражение реалий современного мира и пытается выявить в нем идеи, которые могут быть использованы при реализачии справедливости в условиях современного общества. Автор исследует проект справедливого общества А. М. Ковалёва под углом зрения единства всех сфер общественной жизни, причинных и функииональных связей, под углом зрения взаимосвязи и взаимообусловленности потребностей, интересов и иенностей. Конщепџия справедливости А. М. Ковалева представляется интересной и оригинальной. Она отражает умонастроения определённых социальных слоёв общества и их пожелания. Наиболее интересным в воззрениях А. М. Ковалёва представляется положение, согласно которому частная собственность, социальное и классовое неравенство - это своеобразный результат адаптации общества к неблагоприятным условиям среды. Положения данной концепци требуют своего дальнейтего более глубокого исследования 6 контексте нынешних и последующих соииальных реалий.

Review: The author of the article studies the main ideas and provisions of the project of fair society in philosophy of a modern Russian philosopher Alexander Kovalev. The socially fair and just society is viewed as the project of a possible society of the future. Alexander Kovalev's concept of justice is studied by the author of the present article as an original teaching. The author also views the aforesaid project as the reflection of the realities of the modern world and tries to discover ideas that could be used when implementation the principles of justice in the modern society. The author also studies the project of fair society offered by Alexander Kovalev from the point of view of the unity of all spheres of social life, causal and functional relations and interrelated and interdependent needs, interests and values. Alexander Kovalev's theory of justice is quite interesting and original. It reflects views and desires of particular social layers. The most interesting part of Alexander Kovalev's theory is his provision that private property as well as social and class-specific inequality are a certain result of adaptation of the society to the difficult environment. Provisions of Kovalev's theory need to be studied more from the point of view of current and future social realities.
\end{abstract}

Ключевые слова: Справедливость, свобода, равенство, собственность, мораль, личность, природа человека, потребности, интересы, ценности.

Keywords: justice, freedom, equality, property, morals, personality, human nature, needs, interests, values.

П роблема справедливости во все времена была актуальной в различных обществах, и с учетом конкретно-исторических условий тот или иной аспект справедливости выходил на первое место. В России во все времена преимущественно рассматривали морально-нравственный аспект справедливости, но в последние десятилетия все чаще стали исследовать различные аспекты справедливости, в том числе, экономический и политический. В современной России имеет место определённая дискуссия вокруг проблемы справедливости, дискуссия между политическими партиями, общественными движениями, представителями общественных наук, в том числе и философии.
В свете исследования проблемы справедливости вызывают особый интерес воззрения современного российского философа А. М. Ковалева, воззрения, которые являются попыткой создания проекта справедливого общества. Ковалёв Александр Митрофанович в своём произведении «Справедливое общество - утопия или возможность» рассматривает социально-справедливое общество как проект возможного общества будущего, выдвигая очень интересные, оригинальные мысли и обогащая концепцию справедливости ${ }^{1}$. Мы не пытаемся изложить здесь ос-

${ }^{1}$ Ковалёв А.М. Справедливое общество - утопия или возможность. М., Современные тетради, 2005. - 698 с. 


\section{Политика и общество 3 (111) • 2014}

новные моменты всей философии А. М. Ковалева, а только то, что вызывает у нас наибольший интерес в рамках проблемы справедливости.

В своей концепции справедливости А. М. Ковалёв сразу обозначает основные методологические принципы, от которых он отталкивается в своём исследовании справедливости и проекте социально-справедливого общества будущего. Он считает, что объективные основы, та почва, которая питала и питает благородные устремления людей к миру, справедливости и счастью; они коренятся в тех всеобщих естественных законах, которые заключены в человеческой природе, в природных основах общественной жизни. Эта самореализация происходит на основе определённых естественных законов, определяющих те контуры будущего общества, в которых оно может быть воплощено. При этом речь может идти лишь о контурах, так как всеобщие законы человеческой природы реализуются конкретно в зависимости от условий ${ }^{2}$.

А. М. Ковалев отмечает две крайности, которыми характеризуются прогнозы, касающиеся общества будущего. Многие авторы, считает он, при анализе будущего исходят из одной биологической основы человека, недооценивая, в тоже время, его социальную сущность. В соответствии с этим, они считают, что и будущее общество не способно решить коренные насущные проблемы человечества, воплощенные в его идеалах.

Другая крайность заключается в том, что общество рассматривается лишь под углом зрения одних социальных условий и игнорирования его биологической основы, что также приводит к односторонности идеализации будущего. Однако при этом упускается из вида, что производство, социальные условия могут воздействовать на жизнь общества лишь в пределах, которые ограничены коренными законами, заключенными, как во внутренней природе человека, так и в окружающей общество природе.

А. М. Ковалёв полагает, что законы, заключенные в человеческой природной основе носят более фундаментальный характер, нежели законы, возникающие на основе того или иного конкретного способа материального производства, что лишь при анализе человеческого потенциала возможно раскрыть коренное отличие социально-справедливого общества будущего от всех предшествующих. Он считает, что раньше

\footnotetext{
${ }^{2}$ Ковалёв А.М. Справедливое общество - утопия или воз-
} можность. М., 2005. - 698 с. С. 5. создавалась иллюзия, что не человек, а производство находится в центре развития и определяет все законы поведения и деятельности людей. Вместо законов производства самого человека на первый план выдвигались законы материального производства ${ }^{3}$.

А. М. Ковалев указывает, что некоторые авторы (Р. Арон, 3. Фрейд, Э. Фромм) отмечают, что социально справедливое общество построить невозможно, так как, по их мнению, сущность человека биологическая, человек иррациональное животное и агрессивное существо. Однако эти авторы, считает он, исходят из ложной посылки при характеристике человеческой природы. Конечно, человеку присущи и черты иррационального поведения, поскольку его вторичные качества запрограммированы. Но в своих коренных качествах, которые выступают определяющими в поведении человека, он характеризуется также единством, сотрудничеством, взаимопомощью и т.п. А. М. Ковалёв уверен, что общество представляет определённую органическую целостность, которая находит свое проявление в единстве общественнотрудовой и исторической деятельности людей. Именно поэтому оно представляет более устойчивое образование по сравнению с другими биологическими видами. «И это естественно, так как человек создает условия своей социальной жизни не индивидуально, а коллективно. Вместе с тем в отношениях между человеческими индивидами в рамках общества имеют место различные взаимоотношения, в том числе сотрудничества и взаимопомощи. При этом отношения сотрудничества преобладают, иначе не существовало бы общества как такового» ${ }^{4}$.

А. М. Ковалёв не согласен с теми, кто считает, что собственность есть врожденная способность и господствующая наклонность. Он отмечает, что в систему ценностей некоторых народов (например, индейцев) не входит понятие частной собственности. Следовательно, частная собственность не является врожденной сознанию человека чертой или импульсом. При этом стремление к частной собственности следует отличать от стремления человека к собственности вообще. Люди стремились к общественной собственности «не только потому, что частная собственность выступала основным проявлением неравенства и одной из

\footnotetext{
${ }^{3}$ Ковалёв А.М. Справедливое общество - утопия или возможность. М., 2005. - 698 с. С. 7 - 9.

${ }^{4}$ Ковалёв А.М. Справедливое общество - утопия или возможность. М., 2005. - 698 с. С. 13 - 14.
} 
причин эксплуатации человека человеком, но и потому, что общество представляет определенный целостный организм, а между тем частной собственностью оно как бы разрывалось на изолированные части» ${ }^{5}$.

Он утверждает, что без знания природы человека, без учёта того, что человеку нужно, нельзя дальше развивать нашу общественную науку 6 . Природу человека, человеческий потенциал в целом следует рассматривать только в сочетании со способом производства материальных благ, а также с той природной средой, в которой функционирует то или иное общество. Всё это «в совокупности и порождает определенный способ производства общественной жизни со всеми его особенностями и своеобразием как в стадиальном (историческом), так и в горизонтальном (региональном) планах» ${ }^{7}$.

Мы согласны с тем положением А. М. Ковалёва, что природная среда в некоторой мере определяет деятельность человека и общественное развитие в целом, но мы не считаем, что природная среда, географические условия являются в общественной жизни определяющими в наибольшей мере. Они являются одним из источников общественного развития, но не самым главным. Правда, этого не утверждает и А. М. Ковалёв, но нам представляется, что он отводит природной среде бо́льшую роль в жизнедеятельности человека, чем это есть в действительности.

«Исторический опыт прямо указывает на то, что движение и смена форм собственности в значительной степени зависят от характера орудий и средств производства, которыми оперирует то или иное общество. Мелкие орудия труда связаны больше с индивидуальным использованием. Современные же крупные производительные силы все более настоятельно требуют своего коллективного использования и применения», - пишет А. М. Ковалёв и делает вывод о необходимости обобществления средств производства ${ }^{8}$.

А. М. Ковалёв говорит об обеспечении простора для лучших сторон природы человека, создании адекватных условий для самореализации человека. Он по-

\footnotetext{
${ }^{5}$ Ковалёв А.М. Справедливое общество - утопия или возможность. М., 2005. - 698 с. С. 16.

${ }^{6}$ Ковалёв А.М. Справедливое общество - утопия или возможность. М., 2005. - 698 с. С. 18.

7 Ковалёв А.М. Справедливое общество - утопия или возможность. М., 2005. - 698 с. С. 21.

${ }^{8}$ Ковалёв А.М. Справедливое общество - утопия или возможность. М., 2005. - 698 с. С. 22.
}

лагает, что человек стремится к насилию лишь тогда, когда отсутствуют условия, благоприятствующие проявлению его социально-природной сущности. «При наличии необходимых условий он, как правило, стремится обеспечить себя всем необходимым ненасильственными путями. Ведь не борются же между собой люди, например, из-за воздуха, хотя если бы его было недостаточно, он превратился бы в объект спекуляции, борьбы и насилия. Следовательно, насилие в обществе, в конечном счете, не самоцель» ${ }^{9}$.

Мы полагаем, что в любом случае в обществе необходимо создавать всяческие условия для реализации личностного потенциала. Если же эти условия отсутствуют, то человек может направить свои способности в иное неправильное русло.

А. М. Ковалев считает, что проблема собственности имеет такое значение для человека лишь потому, что с ней связаны источники существования. Поскольку человек лишен возможности получить необходимые средства жизни из общественных фондов, он стремится обзавестись своими собственными источниками существования.

По этому поводу отметим, что человек имеет естественное право самостоятельно решать обзавестись ему собственным источником существования или надеяться на общественные фонды. Что касается общественных фондов, то ими должны пользоваться те, кто своим трудом создаёт эти фонды, за исключением тех, кто не способен на это по объективным причинам.

С точки зрения А. М. Ковалёва интерес общества как более общий и коренной доминирует над интересами индивида. Именно на основе господства в обществе всеобщего интереса возникли в свое время эксплуататорские классы. Он считает, что личный интерес у человека на первом плане лишь потому, что общественные интересы, как доминирующие и господствующие еще удовлетворяются и прокладывают себе дорогу чаще всего за счет и в ущерб интересам личности. Поэтому личность и ставит свой интерес на первый план, охраняя его от покушения общества ${ }^{10}$.

Рассматривая аргументы тех, кто, исходя из природы человека, пытается доказать вечный характер частной собственности и невозможность утверждения социально-справедливого общества, А. М. Кова-

\footnotetext{
9 Ковалёв А.М. Справедливое общество - утопия или возможность. М., 2005. - 698 с. С. 25.

${ }^{10}$ Ковалёв А.М. Справедливое общество - утопия или возможность. М., 2005. - 698 с. С. $27-28$.
} 


\section{Политика и общество 3 (111) • 2014}

лёв отмечает, что вся аргументация оппонентов исходит из индивидуальной природы человека, тогда как человеческий индивид - элемент определенной социально-природной целостности или, точнее, социально-природного организма, который также обладает соответствующими естественными тенденциями, по разному адаптируется к условиям. А поскольку на пути такой рациональности встает частная собственность и связанная с ней конкуренция и распри между людьми, то и они рано или поздно будут преодолены. А этого аспекта проблемы как раз и не учитывают сторонники вечности частной собственности.

На основании вышеизложенного следует различать стремление человека к собственности вообще и к частной собственности. Природа человека не против общественной собственности и социально-справедливого общества. Она лишь против того, чтобы его провозглашать и утверждать без наличия для этого необходимых предпосылок, т.е. полного достатка для всех его членов материальных ресурсов. Вместе с тем она и против того, чтобы это общество изображать в качестве некого царства сплошной доброты, единства и справедливости без каких-либо проблем ${ }^{11}$.

А. М. Ковалёв считает, что производительные силы оказывают влияние на жизнь общества лишь в порядке обратной связи. Фундаментальные же законы общественного развития, определяющие его структуру, в том числе и причины развития самих производительных сил, заключены в природных основах общества, где воплощены наиболее общие законы не только социальной, но живой и неживой материи. Именно в природных основах следует искать ответы на поставленные вопросы, так как причины этих явлений лежат в глубинах общественного развития и даже мира в целом ${ }^{12}$.

Что касается нашей позиции по данному пункту, то мы считаем, что развитие производительных сил общества обусловлено постоянным возрастанием и возвышением человеческих потребностей. Мы уверены, что это постоянное возрастание обусловлено самой природой человека.

Чем менее благоприятна для существования окружающая среда, тем больше она должна быть компенсирована устойчивостью и активностью самой структуры. Этот закон, отражая необходимость сохранения

\footnotetext{
${ }^{11}$ Ковалёв А.М. Справедливое общество - утопия или возможность. М., 2005. - 698 с. С. 32.

${ }^{12}$ Ковалёв А.М. Справедливое общество - утопия или возможность. М., 2005. - 698 с. С. 33.
}

и поддержания динамического равновесия, присущ как материальному миру в целом, так и миру живой природы, в том числе, человеку. Известно, что растения и животные из-за возможных потерь в непредсказуемых условиях плодятся намного больше, чем позволяет окружающая среда. При этом «человек, обладая адаптационными возможностями и способностями всех предшествующих структур мироздания, прибавил к ним качественно новую, более высокую форму адаптации, - способность создавать для себя с помощью трудовой деятельности искусственную среду и адекватные условия существования» ${ }^{13}$.

А. М. Ковалёв считает, что в условиях неадекватности и недостаточности система стремится сузить свои потребности и искусственными средствами увеличить свои ресурсы. В неблагоприятных условиях среды члены общества, его различные структуры могут жить одна за счёт ограничения другой. Это касается не только отношений между индивидами, но также и отношений между народами, что сопровождается социальным неравенством, эксплуатацией, войнами и т.д. Он делает интересный вывод, что частная собственность, социальное и классовое неравенство - это своеобразный результат адаптации общества к неблагоприятным условиям среды. Он полагает, что для того, чтобы преодолеть классы и эксплуатацию человека человеком, необходимо устранить естественное несоответствие между обществом и природой, его ограниченность.

А. М. Ковалёв советует при анализе социальной структуры общества учитывать не только влияние условий, но и характер адаптации самого общества к этим условиям. Вместе с тем, характер адаптации всего общества к окружающей среде обусловливает также и поведение индивидов, их отношение к обществу и между собой. Он делает вывод, что подлинная демократия может существовать не всегда, а лишь при определённых условиях, когда вторая природа позволяет компенсировать или ослабить динамическое неравновесие со средой ${ }^{14}$.

А. М. Ковалёв выдвигает ещё одно очень интересное положение своей концепции справедливости, которое не совсем бесспорно. Он считает, что в обществе также находит своё проявление закон преимущественного развития, который действует в рамках всей при-

\footnotetext{
${ }^{13}$ Ковалёв А.М. Справедливое общество - утопия или возможность. М., 2005. - 698 с. С. 34 - 36.

${ }^{14}$ Ковалёв А.М. Справедливое общество - утопия или возможность. М., 2005. - 698 с. С. 37 - 39.
} 
роды. При отсутствии дефицита материальных ресурсов, времени, пространства и т.д. действие этого закона происходит таким образом, что структуры или человеческие индивиды, обладая определёнными преимуществами, могут реализовывать себя без ущерба для других. В условиях же дефицита для нормального и свободного функционирования преимущественное развитие одних индивидов может совершаться путём притеснения за счёт других.

В условиях первобытного строя такое ограничение одних и жизнь за их счёт других были невозможны, так как в силу слабости развития второй природы и наличия в то же время острейшего дефицита средств существования это могло бы привести к гибели всей целостности или, во всяком случае, её большинства. Поэтому в тех условиях самоограничение развития общества совершалось за счёт всех его членов, а при трагических обстоятельствах и путём выравнивания или уничтожения части общины, в первую очередь, стариков и детей. Добавим, что это было требованием суровой необходимости.

До тех пор, пока общество не достигнет определённого уровня культуры, более целесообразно, чтобы направление его развития осуществлялось не всеми, а его наиболее передовой и организованной частью в лице определённых прогрессивных классов или партий, пишет он. В процессе развития сначала растёт и увеличивается разрыв между бедными и богатыми, а затем он постепенно уменьшается и преодолевается. Это вытекает из того, что неравенство не должно подрывать целостность системы, или иначе говоря, закон преимущественного развития действует в рамках целостности, обеспечивая её оптимальное развитие. И если он приходит в противоречие с интересами целостности, то рано или поздно общество такое положение устраняет. Следовательно, на определённом этапе развития общество невозможно без имущественного и социального неравенства. Важно лишь, чтобы такое неравенство не выходило за определённые пределы и не подрывало бы закон обеспечения целостности, считает он, и как бы мы сказали, в соответствии с естественноисторической необходимостью. При первобытном строе в силу крайней неадекватности условий общество не могло себе позволить ускорение развития даже путём выделения своего наиболее активного меньшинства ${ }^{15}$.

${ }^{15}$ Ковалёв А.М. Справедливое общество - утопия или возможность. М., 2005. - 698 с. С. $40-46$.
А. М. Ковалёв считает, что в основе общественных процессов лежат не общественно-экономические формации, а общество с его внутренней сущностью, которую условия, в том числе и производительные силы, могут лишь модифицировать в том или ином направлении.

Для более полного анализа развития общества необходим учёт не только социального и естественного в самом человеке, но и социального и природного в условиях его существования. А для этого категория способа производства материальных благ, отражающая производственную структуру общества, недостаточна. Он предлагает более широкую категорию способа производства общественной жизни в целом, в основе которой лежит не производство, а сам человек, и которая включала бы в себя способ производства собственной жизни. В данном случае берётся человек в определённых природно-социальных условиях, а общество функционирует как определённый целостный природно-социальный организм.

А. М. Ковалёв утверждает, что способ производства общественной жизни позволяет представить в единстве формационную и цивилизационную теории, а также концепции постиндустриализма. Если общественные формации - продукт развития материального производства, то цивилизационные - результат глобальных различий природной среды. При этом в различных цивилизационных регионах могут возникать различные цивилизационные структуры. Способ материального производства даёт основу для выделения в структуре общества общественно-экономических формаций, а способ общественного производства - для анализа цивилизации ${ }^{16}$.

Он полагает, что на первый план следует ставить производство собственной жизни, а не материальное производство. Не должен иметь место примат производства над производством человека ${ }^{17}$.

А. М. Ковалёв считает, что природно-социальный организм не может постоянно находиться в извращённом состоянии и самоограничении. Общество рано или поздно должно выйти из своего нынешнего извращённого состояния и все органы и части получат простор для оптимальной самореализации ${ }^{18}$.

\footnotetext{
${ }^{16}$ Ковалёв А.М. Справедливое общество - утопия или возможность. М., 2005. - 698 с. С. 57 - 59.

${ }^{17}$ Ковалёв А.М. Справедливое общество - утопия или возможность. М., 2005. - 698 с. С. 70.

${ }^{18}$ Ковалёв А.М. Справедливое общество - утопия или возможность. М., 2005. - 698 с. С. 100.
} 


\section{Политика и общество 3 (111) • 2014}

В зависимости от различного соотношения между социальными и природными компонентами общественной жизни складывалось и соотношение между общим и индивидуальным интересами, а равно и степень свободы, как общества, так и личности. Социально-справедливое общество вытекает не только и не столько из сложившихся условий, сколько представляет результат развития самого человека, заключённых в его природе тенденций. Будущее социально-справедливое общество - это не просто определённый уровень материального производства или второй природы, а определённая степень самореализации потребностей, способностей и интересов общества и личности достигнутая на определённом этапе развития производства ${ }^{19}$.

Коренной особенностью общества будущего должно быть утверждение соответствия между способом материального и духовного производства и способом производства собственной жизни и географической средой. Соответствие различных компонентов способа производства общественной жизни составляет не только самую главную черту будущего общества, но и служит основой всех его других закономерностей и характеристик, в том числе и основного закона ${ }^{20}$.

Человек, человеческий потенциал, хотя и выступают продуктом истории, порождены не только историей, но и всей природой, и содержат в себе не только историческое, но и природное, не только особенное, но и общее. Иными словами, человек - действительно продукт условий, но условий более глубокого и коренного порядка, чем только условия исторические. При этом, воздействуя на внешнюю природу, человек меняет и свою собственную природу ${ }^{21}$.

А. М. Ковалёв называет важнейшие особенности будущей стадии в развитии общества.

1). Окончательно преодолевается несоответствие производительных сил и производственных отношений в рамках способа материального производства.

2). Производимый совокупный общественный продукт достигает таких масштабов, что позволяет обеспечить общественно-необходимые потребности сначала в соответствии с научно-обоснованными

\footnotetext{
${ }^{19}$ Ковалёв А.М. Справедливое общество - утопия или возможность. М., 2005. - 698 с. С. $110-114$.

${ }^{20}$ Ковалёв А.М. Справедливое общество - утопия или возможность. М., 2005. - 698 с. С. 142.

${ }^{21}$ Ковалёв А.М. Справедливое общество - утопия или возможность. М., 2005. - 698 с. С. $110-149$.
}

нормами, а затем и по потребности. А это приведёт к принципиальному изменению всей общественной структуры и её конкретных форм проявления.

3). Утверждение полного (не в смысле абсолютного) соответствия между способом материального и духовного производства и способом производства собственной жизни (в рамках всего способа общественного производства).

4). Специфические общественные формы и институты, а также их законы не опосредованно, а уже непосредственно и прямо начнут соответствовать всеобщим законам человеческой природной основы и отражать их.

5). Утверждение адекватности между обществом в лице его обоих внутренних компонентов и географической средой ${ }^{22}$.

Исходя из нашего понимания человеческой природы, исходя из факта постоянного возрастания человеческих потребностей, нам представляется, что «окончательное преодоление несоответствия производительных сил и производственных отношений» не может быть достигнуто полностью. Это соответствие, считаем мы, может быть только временное и относительное. Что касается совокупного общественного продукта, то каким бы ни был его масштаб, мы полагаем, что «распределение по потребностям» очень спорно и маловероятно.

А. М. Ковалёв справедливо указывает на необходимость равных и оптимальных стартовых возможностей. Он считает, что в социально-справедливом обществе будущего главным является не создание равных стартовых возможностей для развития личности. Равные стартовые возможности можно создать и в условиях «уравниловки» при крайне низком уровне экономического развития. «Следует, по-видимому, говорить о создании не столько равных, сколько оптимальных условий для развития человеческой личности» ${ }^{23}$.

Подлинное равенство заключено в представлении равных социальных возможностей для проявления всех качеств и свойств человеческой личности. Но в принципе равенства также таится известное противоречие между равным правом обеспечения возможностей человеческих индивидов и неравными естественными способностями самих этих индивидов. А это

\footnotetext{
${ }^{22}$ Ковалёв А.М. Справедливое общество - утопия или возможность. М., 2005. - 698 с. С. 157.

${ }^{23}$ Ковалёв А.М. Справедливое общество - утопия или возможность. М., 2005. - 698 с. С. 181.
} 
таит также определённую несправедливость, но уже не экономического, а естественного порядка. И обществу в будущем следует преодолеть эту естественную несправедливость ${ }^{24}$.

Мы считаем, что природа не может быть несправедливой. Всякие сомнения по поводу «справедливости природы», желание нарушить то неравенство, что создано природой, в пользу тех, «кем пренебрегла природа», любое искусственное выравнивание людей может только отбросить общество к низкой производительности труда и равенству нищеты ${ }^{25}$.

Весьма спорно и тенденциозно А. М. Ковалев говорит, что «на место социального неравенства и борьбы между индивидами утверждается социальное равенство и отношения сотрудничества и взаимопомощи. Различные сферы социальной жизни приходят в гармоническое единство между собой» ${ }^{26}$.

Мы полагаем, что достижение такого уровня материального благополучия и иных ценностей, чтобы это благополучие привело индивида к отказу от борьбы, весьма затруднительно в связи с постоянным ростом человеческих потребностей, а также амбиций. Человек борется «за место под солнцем» не только с целью выживания, но нередко и ради достижения первенства в качестве самоцели.

А. М. Ковалёв пишет, - «Характерная особенность природы человека состоит в том, что при недостатке материальных средств жизни человеческий индивид не только стремится запастись всем необходимым, но и создать определённый запас на будущее. Таким своеобразным гарантированным запасом жизненных средств выступает на определённом этапе при неадекватности условий потребностям общества частная собственность» ${ }^{27}$.

Он надеется, что удастся создать такой запас материальных средств, что можно будет преодолеть стремление человека к частной собственности. Он полагает, что в обществе будущего вероятнее всего будут существовать две формы собственности - общественная и личная. Общество будущего не

\footnotetext{
${ }^{24}$ Ковалёв А.М. Справедливое общество - утопия или возможность. М., 2005. - 698 с. С. 440.

${ }^{25}$ Исмаилов Н. О. Справедливость как мера равенства // Социология власти. М., 2009, № 8. С. 95 - 103.

${ }^{26}$ Ковалёв А.М. Справедливое общество - утопия или возможность. М., 2005. - 698 с. С. 208.

${ }^{27}$ Ковалёв А.М. Справедливое общество - утопия или возможность. М., 2005. - 698 с. С. 335.
}

устранит личной собственности, которая необходима для всестороннего развития личности. Устраняя частную собственность, будущее общество не только не ведёт к потере свободы и самостоятельности человеческой личности, напротив, впервые создаёт для этой свободы и самодеятельности необходимый простор. «Человеческая личность, освобождённая от страха разорения, потери своего крохотного клочка земли, лавки или мастерской, имеющая возможность получить из общественных фондов всё необходимое для себя, станет впервые действительно свободной и сможет зажить действительно полнокровной свободной творческой жизнью» ${ }^{28}$.

На наш взгляд, страх разорения не означает, что человек не может и не должен стремиться к частной собственности. Если А. М. Ковалёв считает, что при частной собственности свобода является иллюзорной, то мы полагаем, что частная собственность, наоборот, делает человека независимым от вышестоящих и иных инстанций. Благодаря этой собственности человек объективно имеет возможность развивать свои способности, повышать свой личностный уровень ${ }^{29}$. Нам представляется, что страх разорения вынуждает индивида быть более ответственным и прилагать большие трудовые усилия.

Но далее А. М. Ковалёв высказывает очень интересные мысли, что при острейшем недостатке материальных ресурсов собственность становится всеобщим достоянием, и это достояние распределяется на основе строгой «уравниловки». После же достижения определённого достатка, который обеспечивает выживание всех, но при отсутствии изобилия, распределение собственности происходит таким образом, чтобы она попадала в распоряжение и обеспечила доминирование наиболее сильных, предприимчивых индивидов над более слабыми. Тем самым достигается возможность, чтобы ограниченные материальные ресурсы в первую очередь попадали в руки тех, кто может обеспечить им наиболее рациональное увеличение и тем самым дать большую жизненность социальному целому, создав возможность для его более успешного продвижения вперёд. Он делает вывод, что «в условиях изобилия собственность также становится обществен-

\footnotetext{
${ }^{28}$ Ковалёв А.М. Справедливое общество - утопия или возможность. М., 2005. - 698 с. С. $336-338$.

${ }^{29}$ Исмаилов Н. О. Собственность как объективная основа справедливости и свободы // Гуманитарные и социально-экономические науки. - Ростов-на-Дону, 2009, № 1. С. 54 - 58.
} 


\section{Политика и общество 3 (111) • 2014}

ным достоянием, а её индивидуальное пользование и различие теряют силу» ${ }^{30}$.

А. М. Ковалёв справедливо утверждает, что свободный и творческий труд доставлял и доставляет человеку глубокое удовлетворение. Свобода от труда это мечта раба, но не свободного труженика общества. Он говорит о выравнивании характера, содержания и условий труда тружеников города и деревни, о превращении сельскохозяйственного труда в разновидность индустриального. Также он говорит о сближении физического и умственного труда ${ }^{31}$.

Мы считаем, что сближение физического и умственного труда не противоречит принципу справедливости, но этот процесс должен быть результатом саморазвития человеческой деятельности и общественных отношений; не следует превращать этот процесс в самоцель, не следует внедрять и навязывать его искусственно. Согласно нашему пониманию справедливости каждый человек должен заниматься своим делом согласно его способностям, но опять-таки к этому нельзя принуждать.

А. М. Ковалёв полагает, что превращение труда в важнейшую жизненную потребность человека в обществе будущего будет означать не что иное, как реализацию естественной потенции человека, его способности трудиться в определённой сфере деятельности ${ }^{32}$. «Сначала человек трудился под угрозой голода (первобытный строй), затем труд стал совершаться под угрозой насилия (рабство, феодализм). На современном этапе труд совершается главным образом под влиянием материальных стимулов. Лишь в обществе будущего труд превратится в деятельность свободного индивида в соответствии с его естественными интересами и склонностями»,- надеется он ${ }^{33}$.

«Отчуждение труда индивида и его продуктов в пользу общества может происходить различными путями. Один путь - это отчуждение продуктов труда посредством определённого господствующего класса и второй - посредством и в пользу государства. Но и в том, и в другом случае и данный класс, и государ-

\footnotetext{
${ }^{30}$ Ковалёв А.М. Справедливое общество - утопия или возможность. М., 2005. - 698 с. С. 352.

${ }^{31}$ Ковалёв А.М. Справедливое общество - утопия или возможность. М., 2005. - 698 с. С. 363 - 365.

${ }^{32}$ Ковалёв А.М. Справедливое общество - утопия или возможность. М., 2005. - 698 с. С. 382.

${ }^{33}$ Ковалёв А.М. Справедливое общество - утопия или возможность. М., 2005. - 698 с. С. 410.
}

ство выступают от имени общества и олицетворяют его», - пишет А. М. Ковалёв. То есть здесь полагается, что это обусловлено естественноисторической необходимостью.

А. М. Ковалёв высказывает мысли, которые комуто могут показаться очень глубокими, а кто-то может с ними и не согласиться. Мы же считаем эти мысли очень интересными, но не бесспорными. Он пишет, «Поскольку целое больше своих составных частей, то общество стремится не распылять, а объединять свою социальную энергию и её воплощение в технике, экономике, духовной сфере отдельными концентрированными очагами и, в соответствии с законом преимущественного развития, передавать в распоряжение наиболее энергичных и предприимчивых индивидов».

На основании исторического опыта он делает вывод, что в обществе имеет место своеобразная естественная пирамида, основанная на природных качествах самих индивидов, их различной степени одарённости, ловкости, выносливости и т.п. Он считает, что любая социальная система стремится развиваться через свою наиболее передовую часть путём концентрации энергии на решающих направлениях. «Следовательно, появление в обществе эксплуатации, различных классов, города и деревни, отрыва умственного труда от физического обусловлено действием закона развития живой системы через свою наиболее устойчивую и передовую часть, а также закона концентрации социальной энергии на решающих направлениях общественного развития. ...Однако при отсутствии необходимых условий система начинает концентрировать энергию за счёт самоограничения и ущемления своих собственных менее значимых элементов» ${ }^{34}$.

А. М. Ковалёв надеется, что на смену распределению по собственности, по капиталу придёт принцип распределения по труду ${ }^{35}$. Но мы считаем, что здесь не учитываются риск и организаторские способности предпринимателя. Мы абсолютно уверены, что принцип распределения по труду и заслугам должен в полной мере учитывать и умственные способности, риск, умение организовать производство (или иное дело), умение импровизировать в нестандартной ситуации и т.д. и т.п.

\footnotetext{
${ }^{34}$ Ковалёв А.М. Справедливое общество - утопия или возможность. М., 2005. - 698 с. С. $421-425$.

${ }^{35}$ Ковалёв А.М. Справедливое общество - утопия или возможность. М., 2005. - 698 с. С. 459.
} 
Государство и гражданское общество

А. М. Ковалёв делает главные выводы своего исследования и коротко излагает основные положения своей концепции справедливости. Он указывает, что при объяснении причин существования несправедливости следует исходить из того, что общественная несправедливость есть лишь конкретное проявление процессов, царящих в природном мире в целом. «Разумеется, справедливость и несправедливость - это общественные категории. Однако их корни и основы заложены в неисчерпаемой природе и присущих ей законах» ${ }^{36}$.

Далее он излагает положение, которое, надо полагать, является критерием справедливости согласно его концепции. Он считает, что справедливость, в конечном счёте, - это то, что соответствует закономерному развитию того целого, к которому принадлежит данная структура. Несправедливость же означает устранение или ограничение тех элементов, которые призваны обеспечивать нормальное функционирование целого. Но поскольку целое состоит из своих частей, а общество - из человеческих индивидов, то справедливость реализуется посредством этих индивидов или их сообществ. «В соответствии с этим справедливо будет то, что способствует развитию и обеспечивает оптимальную самореализацию их жизненно здоровых, естественных и социальных начал и потенций, соответствующих развитию целостности. Несправедливо то, что ведёт к их нарушению, ущемлению и, тем более, к устранению. В соответствии с этим способствовать функционированию целого и тем самым поступать справедливо можно как путём активного обеспечения его развития, так и борьбы со всем тем, что стоит на его пути» ${ }^{37}$.

Итак, концепция справедливости А. М. Ковалева представляется нам весьма интересной и оригинальной. Мы в своем исследовании уже отметили достоинства и недостатки данного проекта социально-справедливого общества в свете наших воззрений по проблеме справедливости. Следует подчеркнуть, что данная концепция заслуживает уважения, она отражает умонастроения определённых социальных слоёв общества и их пожелания. Наиболее интересным, хотя и не бесспорным, нам представляется в воззрениях А. М. Ковалёва положение, согласно которому частная собственность, социальное

\footnotetext{
${ }^{36}$ Ковалёв А.М. Справедливое общество - утопия или возможность. М., 2005. - 698 с. С. 681.

${ }^{37}$ Ковалёв А.М. Справедливое общество - утопия или возможность. М., 2005. - 698 с. С. 682.
}

и классовое неравенство - это своеобразный результат адаптации общества к неблагоприятным условиям среды, а также положение о законе преимущественного развития, который действует в рамках не только общественной жизни, но и всей природы. Вызывает также особый интерес категория способа производства общественной жизни в целом и положение, которое можно считать критерием справедливости в концепции А. М. Ковалёва.

Рассмотренные здесь положения интересны и, безусловно, требуют своего дальнейшего более углубленного исследования в контексте нынешних и последующих социальных реалий.

\section{Библиография:}

1. Гаврилова И. Н. Западные трактовки социальной справедливости: обзор концепций // Социологические исследования. 2009. № 3. С. 36-44.

2. Исмаилов Н. О. Собственность как объективная основа справедливости и свободы // Гуманитарные и социально-экономические науки. - Ростовна-Дону, 2009, № 1. С. 54-58.

3. Исмаилов Н. О. Справедливость как мера равенства // Социология власти. М., 2009, № 8. С. 95-103.

4. Исмаилов Н. О. Справедливость как мера свободы // Социология власти. М., 2009, № 7. С. 136-144.

5. Исмаилов Н. О. Устойчивое развитие общества как новая стадия в понимании справедливости // Социология власти. Юбилейный выпуск. М., 2009, № 5. С. 133-139.

6. Кашников Б. Н. Либеральные теории справедливости и политическая практика России. - Великий Новгород, НовГу. 2004. - 260 с.

7. Ковалёв А.М. Справедливое общество - утопия или возможность. М., Современные тетради, 2005. -698 c.

8. Платон. Государство. Законы. Политик. - М.: Мысль, 1998. - 798 с.

9. Ролз Д. Теория справедливости. - Новосибирск, Издательство Новосибирского университета. $1995.536 \mathrm{c.}$

10. Свобода и/или справедливость. Ведомости. Вып. 28 / Под ред. В. И. Бакштановского, Н. Н. Карнаухова. Тюмень: НИИ ПЭ, 2006. - 296с.

11. Судьба государства в эпоху глобализации. Коллективная монография (сборник статей). М.: ИФ PAH, 2005. - 200 c. 


\section{Политика и общество 3 (111) • 2014}

12. Rawls J., Political Liberalism. New-York: Columbia University Press, 1993.

13. Попов Е.А. Понятие государства как ценностносмысловой системы в философии права и философии государственности // NB: Вопросы права и политики. - 2013. - 2. - C. 193-217. DOI: 10.7256/2305-9699.2013.2.454. URL: http://www.enotabene.ru/lr/article_454.html

14. Н.И. Кудринская Аксиологические основания справедливости // Философия и культура. - 2012. - 1. - С. 71-79.

15. И.Н. Титаренко Роль философии в решении глобальных политических проблем и противодействии насилию: античные идеи и современность // Философия и культура. - 2011. - 9. - С. 85-96.

16. Токарева Е.В.. Защита прокурором публичного интереса в гражданском процессе. // Право и политика. - 2014. - № 3. - C. 337-349. DOI: .10.7256/1811-9018.2014.3.11321.

17. Жежко И.В.. Политкорректность в контексте протестных движений. // Тренды и управление. - 2013. - № 4. - C. 103-115. DOI: .10.7256/23079118.2013.4.711

\section{References (transliteration):}

1. Gavrilova I. N. Zapadnye traktovki sotsial'noi spravedlivosti: obzor kontseptsii // Sotsiologicheskie issledovaniya. 2009. № 3. S. 36-44.

2. Ismailov N. O. Sobstvennost' kak ob' 'ektivnaya osnova spravedlivosti i svobody // Gumanitarnye i sotsial'no-ekonomicheskie nauki. - Rostov-na-Donu, 2009, № 1. S. 54-58.

3. Ismailov N. O. Spravedlivost' kak mera ravenstva // Sotsiologiya vlasti. M., 2009, № 8. S. 95-103.
4. Ismailov N. O. Spravedlivost' kak mera svobody // Sotsiologiya vlasti. M., 2009, № 7. S. 136-144.

5. Ismailov N. O. Ustoichivoe razvitie obshchestva kak novaya stadiya $\mathrm{v}$ ponimanii spravedlivosti // Sotsiologiya vlasti. Yubileinyi vypusk. M., 2009, № 5. S. 133-139.

6. Kashnikov B. N. Liberal'nye teorii spravedlivosti i politicheskaya praktika Rossii. - Velikii Novgorod, NovGu. 2004. - 260 s.

7. Kovalev A.M. Spravedlivoe obshchestvo - utopiya ili vozmozhnost'. M., Sovremennye tetradi, 2005. $698 \mathrm{~s}$.

8. Platon. Gosudarstvo. Zakony. Politik. - M.: Mysl', 1998. - $798 \mathrm{~s}$.

9. Rolz D. Teoriya spravedlivosti. - Novosibirsk, Izdatel'stvo Novosibirskogo universiteta. 1995. $536 \mathrm{~s}$.

10. Rawls J., Political Liberalism. New-York: Columbia University Press, 1993.

11. Popov E.A. Ponyatie gosudarstva kak tsennostnosmyslovoi sistemy v filosofii prava ifilosofii gosudarstvennosti // NB: Voprosy prava i politiki. - 2013. - 2 . - C. 193-217. DOI: 10.7256/2305-9699.2013.2.454. URL: http://www.e-notabene.ru/lr/article_454.html

12. N.I. Kudrinskaya Aksiologicheskie osnovaniya spravedlivosti // Filosofiya i kul'tura. - 2012. - 1. - C. 71-79.

13. I.N. Titarenko Rol' filosofii v reshenii global'nykh politicheskikh problem i protivodeistvii nasiliyu: antichnye idei i sovremennost' // Filosofiya i kul'tura. 2011. - 9. - C. 85-96.

14. Tokareva E.V.. Zashchita prokurorom publichnogo interesa v grazhdanskom protsesse. // Pravo i politika. - 2014. - № 3. - C. 337-349. DOI: .10.7256/18119018.2014.3.11321.

15. Zhezhko I.V.. Politkorrektnost' v kontekste protestnykh dvizhenii. // Trendy i upravlenie. - 2013. - № 4. - C. 103-115. DOI: .10.7256/2307-9118.2013.4.711 